\title{
Effect of vasoactive intestinal peptide on cyclic adenosine monophosphate production in enterocytes isolated from human duodenal biopsy specimens
}

\author{
J A Smith, M Griffin, S E Mireylees, R G Long
}

\begin{abstract}
A modification of a cell isolation technique used in animal studies was developed to remove enterocytes from duodenal biopsy specimens. Citrate-ethylenediaminetetra-acetic acid treatment removed enterocytes from any underlying lamina propria and produced single cells and strips of cells. A mean (SEM) of 4.39 $(2.06) \times 10^{6}$ cells was obtained from nine duodenal biopsy specimens. Enterocyte recovery was estimated enzymatically using alkaline phosphatase activity and was found to be $61 \%$. Cytological assessment of the cells with CAM 5.2 showed that $98 \%$ of the cells isolated were enterocytes with an intact brush border. The cells responded well to vasoactive intestinal peptide stimulation in the absence of an exogenously added adenosine triphosphate regenerating system. The addition of vasoactive intestinal peptide to duodenal enterocytes produced a biphasic dose dependent increase in cyclic adenosine monophosphate production. Stimulation of these cells with $10^{-13} \mathrm{M}$ vasoactive intestinal peptide resulted in a $50 \%$ stimulation over basal value while $10^{-6} \mathrm{M}$ vasoactive intestinal peptide led to a fivefold increase in cyclic adenosine monophosphate production. We conclude that duodenal biopsy specimens are a good source of human intestinal cells for the study of enterocyte physiology. The cells were viable and highly responsive to vasoactive intestinal peptide.
\end{abstract}

Vasoactive intestinal peptide (VIP) is a 28 amino acid peptide originally isolated from porcine small intestine by Said and Mutt. ${ }^{1}$ It is believed to be a neurotransmitter and is found extensively throughout the central nervous system and gastrointestinal tract. ${ }^{23}$ It is secreted by non-beta islet cell pancreatic tumours and ganglioneuroblastomas (VIPomas) ${ }^{2-4}$ which are clinically characterised by the watery diarrhoea, hypokalaemia, and achlorhydria (WDHA) syndrome. ${ }^{5}$ Infusion of VIP into the blood of normal man and animals produces the profuse secretory diarrhoea associated with these tumours. ${ }^{6}$ These two pieces of evidence indicate an endocrine role for VIP when high concentrations in plasma are present. Normal plasma values of VIP are thought to be the result of neurone 'dumping' and not to have any physiological function.'

The mechanism by which VIP exerts its effects on intestinal secretion is thought to be through the stimulation of adenylate cyclase and therefore cyclic adenosine 3', 5'-monophosphate production. ${ }^{4}$ Raised cyclic adenosine monophosphate values lead to active $\mathrm{Cl}^{-}$secretion and decreased $\mathrm{Na}^{+}$absorption, the overall effect being net intestinal secretion. ${ }^{8}$

Initial in vitro studies with human intestinal homogenates failed to show VIP induced adenylate cyclase stimulation ${ }^{10}$ at concentrations consistent with those found in the plasma of patients with VIPomas $\left(10^{-11}-10^{-9} \mathrm{~mol} / \mathrm{l}\right) .^{11}$ The possibility therefore arose that the hypothesis that VIP from tumours caused direct enterocyte cyclic adenosine monophosphate production, intestinal secretion, and diarrhoea was flawed. In animal studies isolated enterocytes have been used with greater sensitivity. ${ }^{72-14}$ The purpose of this study was to isolate enterocytes from human duodenal biopsy specimens using a calcium chelation technique ${ }^{15}$ and to assess the effect of VIP in stimulating cyclic adenosine monophosphate production.

Patients and methods

Patients presenting at clinic with diarrhoea or iron deficient anaemia underwent biopsy as part of diagnostic investigations to exclude malabsorption. Duodenal biopsy specimens from 20 of these patients were used to validate the cell isolation technique. All these patients were subsequently found to have normal duodenal histology and no underlying upper intestinal disease.

The six patients used for the VIP studies were all women with a mean (SEM) age of 40 (7) years. After examination, five of the patients were diagnosed as having the irritable bowel syndrome. All had abdominal discomfort or pain, three had mild diarrhoea, and one had increased rectus flatus. The final patient had iron deficiency anaemia for which investigations showed no cause. All these patients had histologically normal duodenal mucosa and normal lactase, sucrase, and maltase values.

The patients were fasted from midnight, and the following morning they were prepared with lignocaine spray to the pharynx and intravenous sedation with diazepam (Diazemuls). An Olympus GIF IT endoscope (Keymed, Southend-onSea, Essex) with $3.7 \mathrm{~mm}$ biopsy forceps was used. Two biopsy specimens were taken from the second part of the duòdenum for histological assessment. Subsequent biopsy specimens were put into $0.9 \%$ saline at $4^{\circ} \mathrm{C}$. Each specimen weighed approximately $13 \mathrm{mg} .{ }^{16}$ The research protocol was approved on ethical grounds by the City Hospital Ethical Committee, Nottingham and the patients gave informed written consent.
Correspondence to:

Dr R G Long, City Hospital, Nottingham NG5 1PB.

Accepted for publication 12 February 1990 
PREPARATION OF ISOLATED ENTEROCYTES

A modification of a cell isolation technique used in animal studies was developed. ${ }^{15}{ }^{17}$ The biopsy specimens were transferred to $10 \mathrm{ml}$ citrate buffer (1.5 mM KCl, $96 \mathrm{mM} \mathrm{NaCl}, 27 \mathrm{mM} \mathrm{Na}$ citrate, $8 \mathrm{mM} \mathrm{KH}_{2} \mathrm{PO}_{4}, 5 \cdot 6 \mathrm{mM} \mathrm{Na}_{2} \mathrm{HPO}_{4}, \mathrm{pH}$ $7 \cdot 3$ ), prewarmed to $37^{\circ} \mathrm{C}$, and incubated for 10 minutes in a shaking water bath. The citrate buffer was removed and the specimens were resuspended in $10 \mathrm{ml}$ ethylenediaminetetraacetic acid (EDTA) buffer (1.5 $\mathrm{mM}$ EDTA, $0.5 \mathrm{mM}$ dithiothreitol, $10 \mathrm{mM} \mathrm{NaH} \mathrm{HPO}_{4}$, $154 \mathrm{mM} \mathrm{NaCl}$ ) at $37^{\circ} \mathrm{C}$ for 30 minutes. The cell suspension was separated from the biopsy fragments and centrifuged for five minutes at $350 \mathrm{~g}$. The pellet of cells was washed twice in TRIS buffer ( $15 \mathrm{mM}$ TRIS, $120 \mathrm{mM} \mathrm{NaCl}, 5 \mathrm{mM} \mathrm{KCl}$,

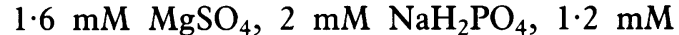
$\mathrm{CaCl}_{2}, 10 \mathrm{mM}$ glucose $\left.\mathrm{pH} 7 \cdot 4\right)$ at $4^{\circ} \mathrm{C}$ and gassed with $5 \% \mathrm{CO}_{2} / 95 \% \mathrm{O}_{2}$. Cells for the study of cyclic adenoşine monophosphate were resuspended in the above TRIS buffer with the addition of $0.1 \%$ bovine serum albumin and $1 \mathrm{mM} 3$-isobutyl-1-methylxanthine to prevent cyclic adenosine monophosphate degradation. Enterocyte viability was assumed because the adenylate cyclase responded well to VIP stimulation in the absence of an exogenously added adenosine triphosphate regenerating system.

Time course studies showed that once the cells were isolated the rate of both basal and VIP stimulated cyclic adenosine monophosphate production was constant for the first 10 minutes of incubation. The brush border membrane enzyme, alkaline phosphatase, was assayed to assess enterocyte recovery from the biopsy specimens. Alkaline phosphatase activity was assayed in the cell suspensions and homogenates of the biopsy specimens from which the cells had been harvested by the method of Hausamen. ${ }^{17} 18$ Cytological assessment of the enterocytes was by staining with CAM $5 \cdot 2,{ }^{19}$ a monoclonal antibody used as a marker for normal human secretory epithelia. Deoxyribonucleic acid assay ${ }^{20}$ showed approximately $50 \mu \mathrm{g}$ deoxyribonucleic acid was equivalent to $1 \times 10^{6}$ cells.

\section{INCUBATION OF ISOLATED ENTEROCYTES \\ WITH VIP}

Synthetic porcine VIP was dissolved in the same TRIS buffer used to suspend the cells with the addition of $4 \mathrm{KIU} / \mathrm{ml}$ aprotinin. Cells (approximately $1.5 \times 10^{6} / \mathrm{ml}$ ) were preincubated for three minutes at $37^{\circ} \mathrm{C}$. The incubation was for a further seven minutes at $37^{\circ} \mathrm{C}$ and the reaction was initiated with the addition of VIP at concentrations ranging from $10^{-13}-10^{-6} \mathrm{M}$. The reaction was terminated with sufficient ice cold trichloroacetic acid to produce a final concentration of $6 \%$. The trichloroacetic acid was removed by amine/Freon extraction. ${ }^{21}$ Cyclic adenosine monophosphate was assayed in the extract by a protein binding assay. ${ }^{22}$

\section{MATERIALS}

All chemicals were of the highest available grade from the Sigma Chemical Company with the exception of $\left({ }^{3} \mathrm{H}\right)$ cyclic adenosine monophosphate which was from Amersham Inc and CAM $5 \cdot 2$ from Becton Dickinson.

\section{STATISTICS}

Results are expressed as mean (SEM). The Wilcoxon signed rank test was used to test for significance.
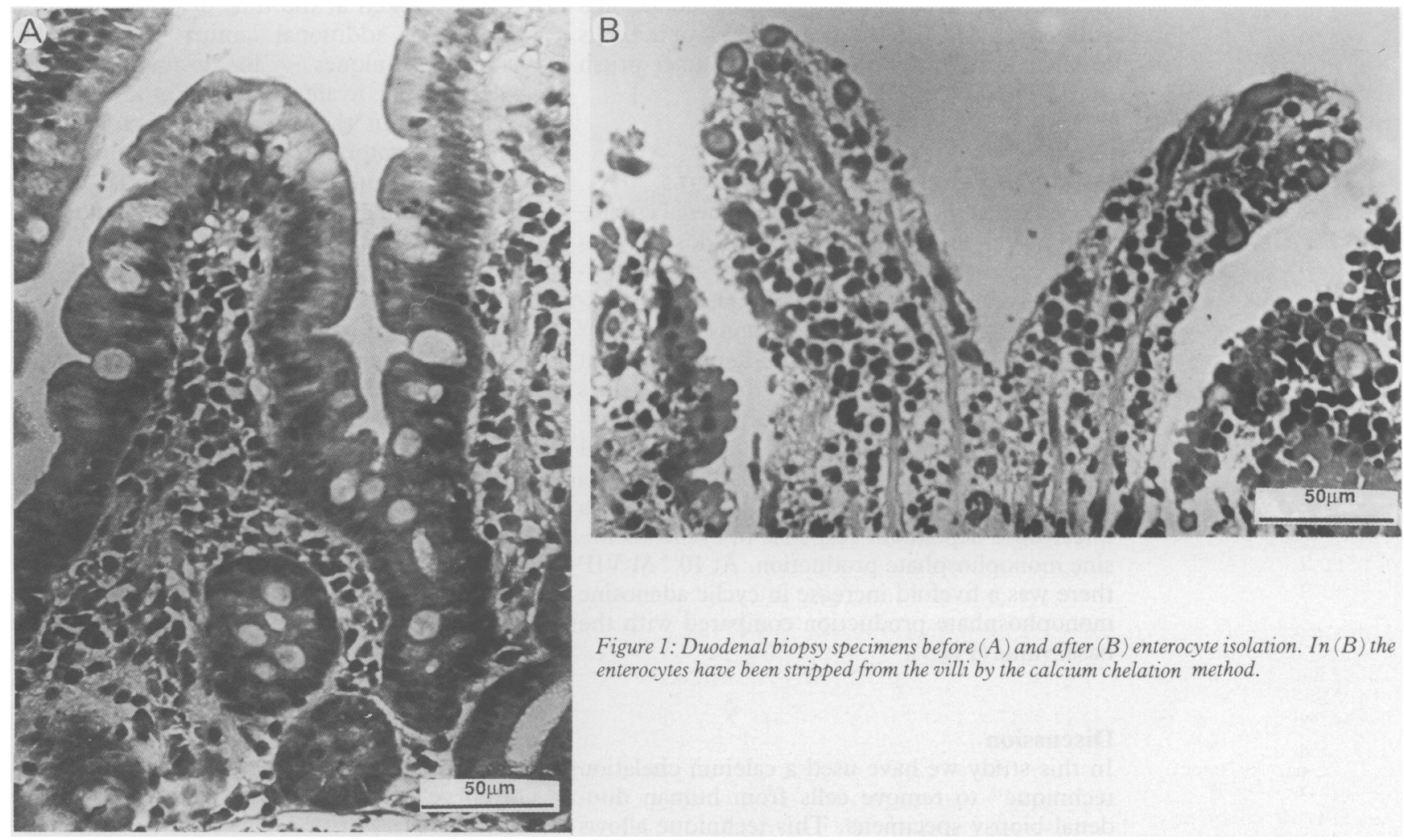

Figure 1: Duodenal biopsy specimens before $(A)$ and after $(B)$ enterocyte isolation. In $(B)$ the enterocytes have been stripped from the villi by the calcium chelation method. 


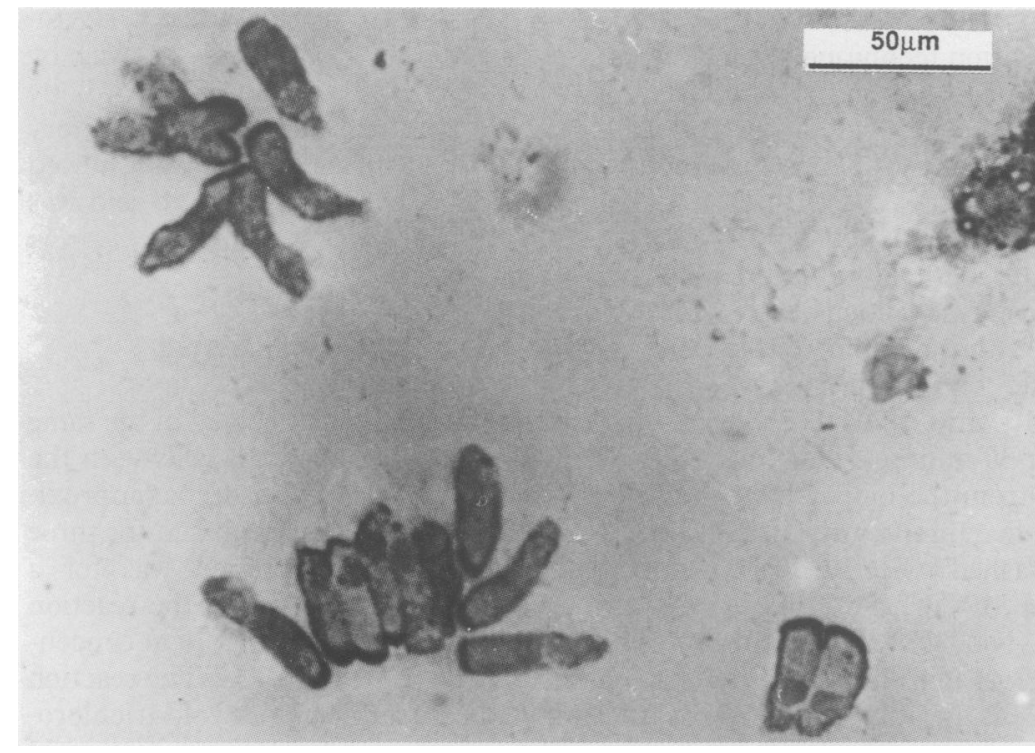

Figure 2: Enterocytes isolated from duodenal biopsy specimens. The darker staining end of the cells is the intact brush border membrane.

\section{Results}

ISOLATED ENTEROCYTES

Figure 1 shows two duodenal biopsy specimens before and after the cell isolation procedure. The citrate/EDTA treatment removed enterocytes from the underlying lamina propria and produced single cells or strips of small numbers of cells. A mean (SEM) of $4.39(2.06) \times 10^{6}$ cells were removed from nine duodenal biopsy specimens $(n=20)$. Alkaline phosphatase activity is expressed as nmol p-nitrophenol $/ \mathrm{min} / \mathrm{mg}$ protein $(n=5)$. Mean (SEM) alkaline phosphatase activity was 1458 (534) in the cell preparations from the biopsy specimens and 1026 (578) in homogenates of the specimens after the cell isolation procedure. This represented an enterocyte recovery of $61 \%$. The monoclonal antibody, CAM 5.2, showed that $98 \%$ of the cells isolated were enterocytes with an intact brush border (Fig 2).

\section{VIP AND HUMAN DUODENAL ENTEROCYTES}

The addition of VIP to isolated duodenal enterocytes seems to produce a biphasic dose dependent increase in cyclic adenosine monophosphate production. Cyclic adenosine monophosphate concentrations in response to $10^{-13}$ $M-10^{-11} M$ VIP were not dose dependent, but they were $50 \%$ higher $(\mathrm{p}<0.05)$ than basal values indicating that even at these very low VIP concentrations there may be an upregulation of adenylate cyclase activity. From $10^{-9} \mathrm{M}-10^{-6} \mathrm{M}$, VIP isolated duodenal enterocytes exhibited a linear dose dependent response in cyclic adenosine monophosphate production. At $10^{-6} \mathrm{M}$ VIP there was a fivefold increase in cyclic adenosine monophosphate production compared with the basal value (Fig 3).

\section{Discussion}

In this study we have used a calcium chelation technique $^{15}$ to remove cells from human duodenal biopsy specimens. This technique allows

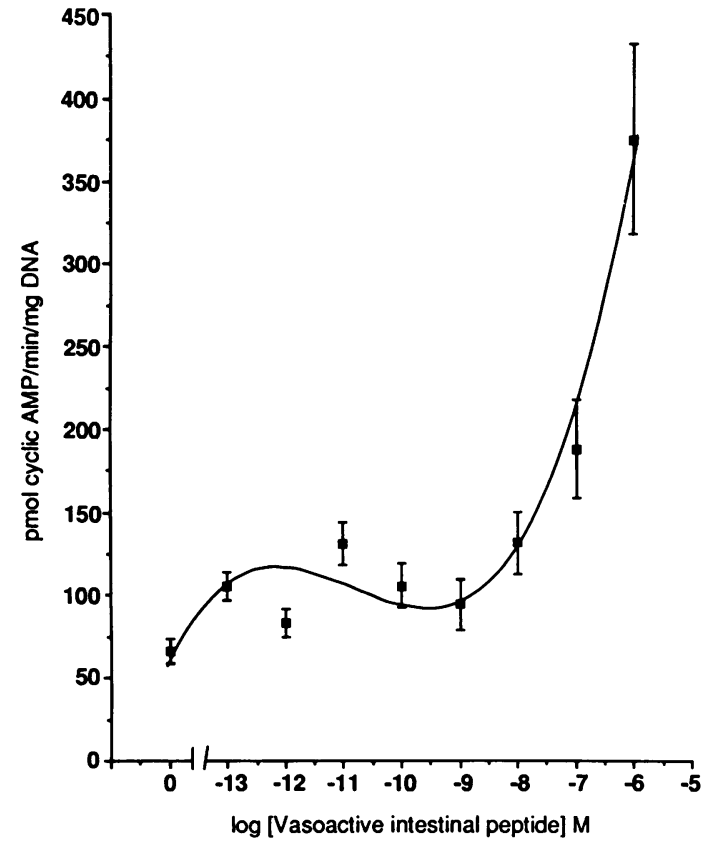

Figure 3: The dose dependent effect of vasoactive intestinal peptide on human duodenal enterocyte cyclic adenosine monophosphate (AMP) production. Data are mean (SEM) of six experiments.

the isolation of cells that are metabolically active and have intact VIP receptors, and should be applicable to other lines of physiological and pharmacological research. It may also be applicable to other disease states, such as treated coeliac disease, in which enterocytes may be recovered from biopsy specimens and used to ascertain primary lesions. However, unpublished efforts by us using biopsy specimens from patients with villous atrophy have not surprisingly failed to produce cells. Other possible techniques are likely to be less successful. Mucosal scrapes from operative or necropsy specimens taken at the time of organ donation will include additional lamina propria cells. Enzyme techniques - for example trypsin, collagenase, or hyaluronidase - produce intact viable cells but the enzymes seem to damage hormone receptors. ${ }^{23}$ Cells in sufficient numbers may be obtained from biopsy material by calcium chelation without undue contamination from underlying non-epithelial tissue. The isolated cells are devoid of neuronal elements and are therefore free from endogenous VIP. ${ }^{24}$

This study provides evidence that VIP stimulates cyclic adenosine monophosphate production in isolated human duodenal enterocytes. The concentration at which VIP stimulation of cyclic adenosine monophosphate could be detected using this cell isolation technique was much lower than that previously reported from human intestinal homogenates ${ }^{90}$ and more sensitive than other isolated epithelial cell preparations. ${ }^{25}$ The shape of the dose response curve is similar to that shown for guinea pig pancreatic acinar cells. ${ }^{26}$ The stimulation of cyclic adenosine monophosphate production seemed to occur in two steps with a first plateau of low amplitude for low VIP concentrations and a second one of larger amplitude for higher VIP concentrations. The curve differs from that of pancreatic acinar cells, however, in that the effective concentra- 
tions of VIP were 100 to 1000 times lower. This seemingly biphasic effect of VIP on human duodenal epithelial cells was different to the monophasic responses reported with rat isolated jejunoileal epithelial cells ${ }^{12}$ and isolated human colonic crypt cells. ${ }^{27}$ The shape of the dose response curve suggests the presence of high and low affinity VIP receptors on these cells. Stimulation of low affinity receptors may be more relevant to the neuronal control of gut function, where nerve terminals in close proximity to epithelial cells could attain high VIP concentrations. ${ }^{28}$ There is, however, some doubt about the physiological relevance of the low affinity VIP receptors. ${ }^{29}$ Stimulation of the high affinity receptors at very low VIP concentrations that give rise to a small but significant cyclic adenosine monophosphate increase fall within both normal blood values and those capable of eliciting intestinal secretion in patients with the VIPoma syndrome." This suggests that either VIP may not have a direct influence upon enterocyte cyclic adenosine monophosphate production in the VIPoma syndrome or that cyclic adenosine monophosphate is not the mediator of intestinal secretion in this disease, and there is some evidence to support both of these ideas. ${ }^{29}{ }^{30-32}$ However, the increase in plasma VIP in VIPoma patients will be in addition to the localised transient neurological VIP already present at the enterocyte basolateral membrane. The increased background values of VIP in combination with the neuronal values may then be sufficient to stimulate the low affinity VIP receptors and generate the large cyclic adenosine monophosphate response and resultant diarrhoea seen in VIPoma patients.

VIP is believed to be cosecreted with at least two other peptides - peptide histidine methionine and peptide histidine valine. ${ }^{33}{ }^{34}$ VIP has been shown to induce small intestinal and colonic secretion of water and electrolytes in human volunteers at plasma values mimicking those seen in patients with the VIPoma syndrome. ${ }^{35} \mathrm{~A}$ similar peptide to peptide histidine methionine and peptide histidine valine - peptide histidine isoleucine - which is found in porcine intestine, has also been infused into normal volunteers and shown to induce intestinal secretion. ${ }^{36}$ Recent human infusion experiments of VIP, peptide histidine methionine and peptide histidine valine to similar concentrations to those seen in the VIPoma syndrome have shown much higher ileal secretion in response to VIP than to the latter peptides. ${ }^{37}$ This has led to the conclusion that VIP is the major mediator and most appropriate marker of the VIPoma syndrome. There is, however, still some doubt about the mechanism of VIP induced secretory diarrhoea.

We conclude that duodenal biopsy material provides a good, readily available source of human enteroctyes for future work on gut physiology. More work is necessary using these cell preparations to discover what other cellular responses are induced by VIP and cyclic adenosine monophosphate.

We are very grateful to the Trent Regional Health Authority for financial support and to Dr J F Mayberry for performing some of the biopsies, Miss J A Smith for technical support with isolating the cells, and Dr I D Ansell and Jane Bell for histological preparation and interpretation.

1 Said S, Mutt V. Isolation from porcine intestinal wall of a vasoactive octasapeptide related to secretin and glucagon. Eur f Biochem 1972; 28: 199-204.

2 Larsson LI. Localization of vasoactive intestinal polypeptide a critical appraisal. In: Said SI, ed. Vasoactive intestinal peptide: advances in peptide hormone research series. New York: Raven Press, 1982: 51-63.

3 Bloom SR, Yiangou Y, Polak JM. Vasoactive intestina peptide secreting tumours: pathophysiological and clinica correlations. Ann N Y Acad Sci 1988; 527: 518-27.

4 Gaginella TG, O'Dorisio TM. VIP: neuromodulator of intestinal secretion. In: Binder HJ, ed. Mechanisms of intestinal secretion. New York: Alan R Liss, 1979: 231-47.

5 Bloom SR, Polak JM, Pearse AGE. Vasoactive intestina polypeptide and watery diarrhoea syndrome. Lancet 1973; ii: polypep.

6 Krejs GJ. Effect of VIP infusion on water and electrolyte transport in human intestine. In: Said SI, ed. Vasoactive intestinal peptide: advances in peptide hormone research series. New York: Raven Press, 1982: 193-200

7 Carmena MJ, Prieto JC, Arilla E, Cacicedo L. Effect of gastroduodenostomy on vasoactive intestinal peptide level and VIP binding and VIP stimulation of cyclic AMP in intestinal epithelial cells from rat. Biochem Med Metab Bio 1987; 37: 307-13.

8 Binder HJ. Net fluid and electrolyte secretion: the pathophysioligic basis for diarrhoea. In: Binder $\mathrm{HJ}$, ed. Mechanisms of intestinal secretion. New York: Alan R Liss, 1979: 1-15.

9 Klaeveman HL, Conelon TP, Levy AG, Gardner JD. Effect of gastrointestinal hormones on adenylate cyclase activity in human jejunal mucosa. Gastroenterology 1975; 68: 667-75.

10 Simon B, Kather H. Activation of human adenylate cyclase in the upper gastrointestinal tracts by vasoactive intestina polypeptide. Gastroenterology 1978; 74: 722-5.

11 Long RG, Bryant MG. Vasoactive intestinal polypeptide. In Bloom SR, Long RG, eds. Radioimmunoassay of gut regulatory peptides. London: W B Saunders, 1982: 231-47.

12 Laburthe M, Priesto JC, Amiranoff B, et al. Interaction of vasoactive intestinal peptide with isolated intestin epithelial cells from rat. Eur F Biochem 1979; 96: 239-48.

13 Vidal H, Comte B, Beylot M, Riou JP. Inhibition of glucose oxidation by vasoactive intestinal peptide in isolated rat oxidation by vasoactive intestinal peptide in

14 Lazo PS, Rivaya A, Velasco G. Regulation by calcium and calmodulin of adenylate cyclase from rabbit intestinal epithelium. Biochim Biophys Acta 1984; 798: 361-67.

15 Weiser MM. Intestinal epithelial cell surface membrane glycoprotein synthesis. $\mathcal{F}$ Biol Chem 1973; 248: 2536-41.

16 Smith JA, Mayberry JF, Ansell ID, Long RG. Small bowel biopsy for disaccharidase levels: evidence that endoscopic forceps biopsy can replace the Crosby capsule. Clin Chim Acta 1989; 183: 317-22.

17 Stern B. Some biochemical properties of suspension of intestinal epithelial cells. Gastroenterology 1966; 51: 855-67.

18 Hausamen TU, Helger R, Rick E, Gross W. Optimal conditions for the determination of serum alkaline phosphatase by a new kinetic method. Clin Chim Acta 1967; 15: 241-5.

19 Moll R, Franke WW, Schiller DL, et al. The catalog of human cytokeratins: patterns of expression in normal epithelia cytokeratins: patterns of expression in normal

20 Kissane JM, Robins E. The fluorometric measurement of deoxyribonucleic acid in animal tissue with reference to the central nervous system. F Biol Chem 1958; 233: 184-8.

21 Khym JX. An analytical system for the rapid separation of ussue nucleotide low pressure on conventional anion exchanges. Clin Chem 1975; 21: 1245-52.

22 Gilman AG. A protein binding assay for adenosine $3^{\prime}: 5^{\prime}$-cyclic monophospate. Proc Natl Acad Sci 1970; 67: 305-12.

23 Trautschold I, Dwenger A. Microtechniques. In: Bergmeyer HU, ed. Methods of enzyme analysis. 3rd ed. Weinheim: Herlag Chemie, 1983: 481-527.

24 Leriag Comient epithelium in health and disease. In: Said SI, ed. Vasoactive epithelium in health and disease. In: Said SI, ed. Vasoactive intestinal peptide; advances in peptide hor

26 Robberecht $P$, Conlon TP, Gardner JD. Interaction of porcine vasoactive intestinal peptide with dispersed pancreatic acinar cells from the guinea pig: structural requirments for effects of VIP and secretin on cellular adenosine $3^{\prime}: 5^{\prime}$ monophosphate. F Biol Chem 1976; 251: 4635-9.

27 Dupont C, Laburthe M, Broyart JP, et al. Cyclic AMP production in isolated colonic epithelial crypts: a highly sensistive model for evaluation of vasoactive intestinal peptide in human intestine. Eur 7 Clin Invest 1980; 10: peptide.

28 Makhlouf MG. Role of VIP in the function of the gut, In: Said SI, ed. Vasoactive intestial peptide; advances in peptide hormone research series. New York: Raven Press, 1982: hormone

29 Robichon A, Marie JC. Selective photolabelling of high and low affinity binding sites for vasoactive intestinal peptide
(VIP): evidence for two classes of covalent VIP receptors (VIP): evidence for two classes of covalent VIP receptors complexes in in

30 Eklund S, Brunsson I, Jodal $M$ and Lungran O. Evidence against CAMP mediated vasoactive intestinal polypeptide induced intestinal secretion. Can f Physiol Pharmacol Suppl Gastrointest Hormones 1986; 132. 
31 Camilleri M, Cooper BT, Adrian TE, et al. Effects of vasoactive peptide in rabbit intestine. Gut 1981; 22: 14-8. $32 \mathrm{Krejs}$ GJ. VIPoma syndrome. Am $\mathcal{F}$ Med 1987; 82 (suppl SB): $37-48$.

33 Bloom SR, Christofides ND, Delamarter J, et al. Diarrhoea in VIPoma patients associated with cosecretion of a second active peptide (peptide histidine isoleucine) explained by single coding gene. Lancet 1983; ii: 1163-5.

34 Long RG, Bryant MG, Mitchell SJ, et al. Clinicopathological study of pancreatic and ganglioneuroblastoma secreting vasoactive intestinal polypeptide (VIPomas)
BrMed F 1981; 282: 1767-71.

35 Kane MG, O'Dorisioo TM, Krejs GJ. Production of secretory diarrhoea by intravenous infusion of vasoactive intestinal polypeptide. N Engl f Med 1983; 309: 1482-5.

36 Moriarty KJ, Hegarty JE, Tatemoto K, et al. Effect of peptide histidine isoleucine on water and electrolyte transport in the human jejunum. Gut 1984; 25: 624-8.

37 Calam J, Yiangou Y, Nikou GC, et al. Effects on ileal output of three peptides secreted by tumours associated with the watery diarrhoea syndrome (WDS). [Abstract]. Gut 1989 30: A748. 